\title{
Penerapan Model Conceptual Understanding Procedures Disertai Mind Mapping Terhadap Pemahaman Konsep Ditinjau Dari Kreativitas Belajar
}

\author{
Indah Putri Dianti $^{1)}$, Akbar Handoko ${ }^{2)}$, Netriwati ${ }^{3)}$ \\ ${ }^{12}$ Pendidikan Biologi, Fakultas Tarbiyah dan Keguruan, UIN Raden Intan Lampung \\ Email: indahputrid24@gmail.com \\ Email: akbarhandoko@radenintan.ac.id \\ ${ }^{3}$ Pendidikan Matematika, Fakultas Tarbiyah dan Keguruan, UIN Raden Intan Lampung \\ Email: netriwati@gmail.com
}
APA Citation: Dianti, I. P., Handoko, A., \& Netriwati, N. (2020). Penerapan Model Conceptual Understanding Procedures Disertai Mind Mapping Terhadap Pemahaman Konsep Ditinjau Dari Kreativitas Belajar. Quagga: Jurnal Pendidikan dan Biologi, 12(1), 85-93. doi: 10.25134/quagga.v12i1.2102.

Received: 23-10-2019

Accepted: 23-01-2020

Published: 30-01-2020

\begin{abstract}
Abstrak: Berlandaskan hasil observasi, kegiatan belajar mengajar biologi masih didominasi dengan metode ceramah dan tanya jawab sehingga pemahaman konsep peserta didik rendah. Perlu adanya perbaikan menggunakan model CUPs dan teknik Mind Mapping. Oleh karena itu, penulis melakukan penelitian untuk mengetahui (1) Perbedaan pemahaman konsep kelas eksperimen menggunakan CUPs dengan kelas kontrol menggunakan Direct Instruction (2) Perbedaan pemahaman konsep yang mempunyai kreativitas belajar tinggi, sedang dan rendah (3) Interaksi antara penggunaan model pembelajaran CUPs dengan kreativitas belajar terhadap pemahaman konsep. Penelitian ini merupakan penelitian kuantitatif. Populasi yang digunakan sebanyak 212 peserta didik kelas XI IPA SMAN 5 Bandar Lampung, dengan Sampel XI IPA 3 sebagai kelas eksperimen dan XI IPA 6 sebagai kelas kontrol. Teknik pengumpulan data adalah tes, angket dan dokumentasi. Tes digunakan untuk mengukur pemahaman konsep, sementara angket digunakan untuk mengukur kreativitas belajar. Pengujian hipotesis Annava Dua Jalan Sel Tak Sama, taraf signifikan 5\%. Diperoleh $\quad F_{a}=119,917>F_{\text {tabel }}=3,989 \quad H_{O A} \quad$ ditolak, $F_{b}=156,271>F_{\text {tabel }}=3,138 \quad H_{O B} \quad$ ditolak, $F_{a b}=61,045<F_{\text {tabel }}=3,138 H_{O A B}$ diterima. Dapat disimpulkan (1) Terdapat perbedaan pemahaman konsep kelas eksperimen dengan kelas kontrol (2) Terdapat perbedaan pemahaman konsep terhadap peserta didik yang mempunyai kreativitas tinggi, sedang dan rendah (3) Tidak terdapat interaksi antara penggunaan model pembelajaran CUPs dengan kreativitas belajar terhadap pemahaman konsep.
\end{abstract}

Kata kunci: Model CUPs; Mind Mapping; Pemahaman Konsep; Kreativitas Belajar.

\begin{abstract}
Based on the results of observations, biology teaching and learning activities are still dominated by lecture and question answer methods, so that students' understanding of concepts is low. There needs to be improvements using CUPs model and Mind Mapping techniques.Therefore, the authors conducted research to find out (1) Differences in understanding the concept of the experimental class using CUPS with the control class using Direct Instruction (2) Differences in understanding concepts that have high, medium, and low learning creativity (3) Interaction between the use of CUPs learning models and learning creativity on concept understanding. This research is a quantitative research. The population used was 212 students of class XI IPA SMAN 5 Bandar Lampung, with Sample XI IPA 3 as an experimental class and XI IPA 6 as a control class. Data collection techniques are tests, questionnaires and documentation. The test is used to measure students understanding of concepts, while the questionnaire is used to measure students learning creativity. The testing of Annava Hypothesis Two Unequal Cell Paths, a 5\% significance level. Obtained $F_{a}=119,917>F_{\text {table }}=3,989 H_{O A}$ rejected, $F_{b}=156,271>F_{\text {table }}=3,138 H_{O B}$ rejected, $F_{a b}=61,045<F_{\text {table }}=3,138$ $H_{O A B}$ accepted. It can be concluded (1) There is a difference in understanding the concept of the experimental class with the control class (2) There is a difference in understanding the concept of students who have high,
\end{abstract}


medium, and low creativity (3) There is no interaction between the use of the CUPs learning model with the creativity of learning towards the concept understanding.

Keywords: Model CUPs; Mind Mapping; Concept Understanding; Learning Creativity.

\section{PENDAHULUAN}

Kegiatan belajar mengajar sangat memberikan dampak bagi pemahaman konsep peserta didik. Kegiatan belajar mengajar merupakan upaya untuk merencanakan sistem dalam merealisasikan hubungan timbal balik pendidik dengan peserta didik sehingga terjadinya komunikasi dalam memahami materi. Kegiatan belajar mengajar pada dasarnya ialah usaha yang dibuat untuk memberikan efek pikiran pada peserta didik. Kegiatan belajar mengajar serupa dengan upaya berlatih peserta didik dengan berbagai jalan, strategi, metode serta pendekatan demi tercapainya proses pembelajaran yang diharapkan (Abdul Majid, 2013).

Salah satu problem yang ada dibidang pendidikan ialah rapuhnya kegiatan belajar mengajar. Selama kegiatan belajar mengajar berjalan, peserta didik minim membangun daya berpikir. Akibatnya, peserta didik pintar secara teoritis, tetapi lemah dalam aplikasi. Hal yang tidak bisa dilupakan demi menggapai tujuan pembelajaran adalah bagaimana upaya mengorganisasikan pembelajaran, mengkoordinasikan isi pembelajaran, dan memobilisasi interaksi antara sumber-sumber belajar yang ada sehingga bekerja secara optimum (Hamzah B. Uno, 2012).

Pembelajaran sains khususnya biologi, peserta didik harus menginterpretasikan suatu konsep, mengaitkan konsep satu dengan konsep lain serta menggunakan konsep yang lain untuk mendukung konsep tertentu. Pembelajaran ini sesuai dengan Kurikulum 2013 dimana proses pembelajarannya aktif. Pedoman baru dalam Kurikulum 2013, pembelajaran di Negara Republik Indonesia ini peserta didik harus aktif dan maksimal. Pendidik berperan hanya sebagai fasilitator di dalam kelas. Peserta didik memiliki peran utama sebagai agen-agen aktif dalam proses pembelajaran di kelas. Peserta didik harus pandai memilih informasi dan membuat pemahaman makna sendiri dari informasi yang mereka dapatkan (Nining Kurniasih dan Nukhbatul Bidayati Haka, 2017).
Permasalahan pada pelaksanaan pembelajaran dapat diatasi dengan penggunaan model pembelajaran yang dapat membantu pendidik dalam melaksanakan kewajibannya mengajar dan mengatasi kesukaran belajar pada peserta didik. Model pembelajaran sebagai acuan rangka konseptul yang mendeskripsikan prosedur yang tertata dalam mengelola pengetahuan tercapainya tujuan belajar (Mohammad Syarif Sumantri, 2016). Model pembelajran yang benar akan membuat peserta didik memahami suatu konsep, mengungkapkan ciri khusus dan umum suatu konsep, serta menjelaskan hubungan antara konsep (La Sahara, 2015).

Salah satu model pembelajaran yang dapat digunakan dalam pembelajaran biologi adalah model pembelajaran Conceptual Understanding Procedures (CUPs). Model pembelajaran Conceptual Understanding Procedures (CUPs) ialah model pembelajaran yang terdiri dari kegiatan pembelajaran dan bertujuan untuk membantu meningkatkan pemahaman konsep peserta didik. Tiga fase pembelajaran CUPs adalah fase kerja individu, fase kerja kelompok, dan fase presentasi hasil kerja kelompok (Nugroho dan P. Dwijananti F Ismawati, 2014). Model pembelajaran CUPs dapat membuat peserta didik lebih sadar tentang bagaimana dan mengapa mereka berpikir dan mencerminkan pemahaman yang lebih baik. CUPs merupakan suatu model pembelajaran yang bertujuan untuk membantu meningkatkan pemahaman konsep yang dianggap sulit oleh peserta didik. Apabila belajar berdasarkan pemahaman konsep secara menyeluruh, bukan hanya sekedar hafalan, pengetahuan yang dimiliki akan lebih bertahan

lama di ingatan dan hal tersebut dapat mengoptimalkan hasil belajar siswa (Kd. Rita Anggreni, I. Gd Meter, dan I Wyn Wiarta, 2013).

Bukan hanya model pembelajaran saja, namun teknik yang cocok juga sangat diperlukan guna memahami materi pelajaran serta mudah mengingat. Pengunaan teknik Mind Mapping dapat membantu dalam 
memahami materi pelajaran yang sedang dipelajarinya. Mind Mapping merupakan cara mencatat yang kreatif, efektif, dan secara harfiah akan memetakan pikiran-pikiran kita. Peta pikiran dikembangkan oleh Tonny Busan pada tahun 1970an didasari pada riset tentang bagaimana cara kerja otak yang sebenarnya. Mind mapping menghubungkan konsep tentang masalah tertentu dari cabang sel saraf untuk membentuk korelasi konsep dengan pemahaman dan hasilnya ditulis langsung di atas kertas dengan animasi yang disukai dan mudah dipahami oleh penulis. Akibatnya, tulisan adalah deskripsi langsung tentang cara kerja koneksi di otak (Muh. Japar Tatang dan Anwar, 2018). Banyak orang yang beranggapan bahwasannya Mind mapping dan peta konsep itu sama. Peta konsep adalah ilustrasi dari grafis konkret yang mengindikasikan bagaimana sebuah konsep tunggal dihubungkan ke konsepkonsep lain pada kategori yang sama, merupakan alat mencatat yang kreatif, efektif, dan akan memetakan pikiran secara harfiah (Nurmiyati Dedy Setiyawan, Meti Indrowati, 2016). Otak manusia sering mengingat informasi dalam bentuk gambar, simbol, suara bentuk, dan perasaan (Awwalia Maulvi L, 2015).

Pemahaman diartikan sebagai pemahaman konsep. Memahami konsep adalah tahap mendasar dan penting dalam serangkaian pelajaran pembelajaran, peserta didik secara langsung dibimbing untuk memahami konsep tersebut. Konsep adalah dasar bagi peserta didik untuk memahami materi yang disediakan oleh pendidik sehingga peserta didik dapat membuktikannya dengan benar sesuai dengan pemahaman mereka (Haris Rosdianto, 2017). Pemahaman konsep peserta didik tidak hanya sebatas mengenal tetapi peserta didik juga harus dapat menghubungakan konsep satu dengan konsep lainnya. Konsep awal yang dimiliki peserta didik sama dengan konsep yang didapatkan selama mendapat pengalaman belajar di kelas, maka konsep tersebut tidak mengalami perubahan tetapi hanya mengalami penambahan konsep. Pemahaman konsep didapatkan pengertian dari kata-kata yang dipelajari. Peserta didik yang kurang mengerti konsep kata-kata akan mengalami kesulitan memahami suatu kalimat yang dibacanya. Pemahaman membuat peserta didik memahami hubungan yang sederhana diantara fakta-fakta atau konsep (Nurma Izzati, 2016).

Dengan begitu, belajar pemahaman konsep memiliki arti penting untuk keberhasilan belajar. Proses pembelajaran yang digunakan menjadi salah satu faktor yang dapat menggerakan peserta didik untuk dapat memahami suatu konsep karena pembelajaran yang baik merupakan pembelajaran yang berpusat kepada peserta didik dan penilaian sebagai bagaian dari evaluasi pencapaian peserta didik.

Pencapaian dalam pembelajaran tidak semata-mata dipengaruhi pada segi kognitif pemahaman konsep saja akan tetapi dapat dipengaruhi juga dari segi psikomotoriknya. Segi psikomotorik tersebut ialah kreativitas (UA Deta, S Widha, 2013). Kreativitas adalah kemampuan yang dimiliki oleh individu dalam mengaktualisasikan diri untuk menciptakan sesuatu yang baru atau kombinasi dari unsurunsur yang telah ada sebelumnya, menjadi suatu karya baru yang dilakukan melalui interaksi dengan lingkungan untuk menghadapi permasalahan dan mencari berbagai alternatif pemecahan masalah (Ibid). Kreativitas adalah elemen mendasar dalam kaitannya dengan pendidikan. Kreativitas membantu peserta didik untuk mencoba konsep yang berbeda, persepsi yang berbeda, dan sudut pandang yang berbeda terhadap masalah (Sunarto, 2018). Oleh karena itu, mempromosikan keterampilan kreativitas peserta didik telah muncul sebagai masalah pendidikan yang penting di beberapa negara seperti: Jepang dan Amerika Serikat (Nooreen Noordin Saeideh Bolandifar, 2013).

Kurang tepatnya penggunaan model dan teknik pembelajaran di dalam kelas dapat membuat peserta didik kurang menguasai konsep yang diberikan. Kesalahan dalam penggunaan model pembelajaran akan sulit untuk mencapai tujuan yang diharapkan dalam belajar. Seperti yang terjadi di sekolah dari observasi secara langsung, umumnya peserta didik hanya menerima materi dari seorang pendidik saja, setelah itu peserta didik diberi tugas untuk menumbuhkan rasa ingin tahu nya 
yang lebih luas namun hal tersebut malah membuat peserta didik hanya mencari nilai terbaik tanpa memahami yang sebenarnya. Dari hal tersebut, maka diperlukan sebuah model pembelajaran baru yang bisa digunakan untuk membuat suasana belajar yang aktif, membangun pemahaman konsep serta memiliki kreativitas belajar untuk mengasah pemahaman konsep peserta didik.

Dengan menggunakan model pembelajaran Conceptual Understanding Procedures (CUPs), diharapkan dapat membentuk suatu perubahan pemahaman konsep biologi dan juga kreativitas belajar peserta didik.

\section{METODOLOGI PENELITIAN}

Penelitian ini merupakan penelitian kuantitatif menggunakan metode penelitian quasi eksperiment. Metode quasi eksperiment dimodifikasi dengan rancangan desain faktorial. Desain faktorial memungkinkan adanya variabel moderator yang mempengaruhi perlakuan (variabel independen) terhadap hasil (variabel dependen). Dalam penelitian ini variabel moderatornya adalah kreativitas belajar peserta didik yang terbagi ke dalam tiga golongan yaitu kreativitas belajar tinggi, sedang, dan rendah. Penelitian ini dirancang dengan desain faktorial $2 \times 3$. Dengan rancangan faktorial demikian, hipotesis-hipotesis yang diajukan dapat diuji sekaligus yaitu pengujian perbedaan utama yaitu perbedaan pemahaman konsep, perbedaan kreativitas belajar peserta didik, dan ada atau tidak adanya interaksi dari kedua variabel tersebut. Desain faktorial $2 \times 3$ memerlukan enam kelompok, dapat dilihat pada tabel di bawah ini.

Tabel 1. Desain Faktorial 2x3

\begin{tabular}{cccc}
\hline \multirow{3}{*}{$\mathbf{A}$ A/B } & \multicolumn{3}{c}{$\mathbf{A}$} \\
\cline { 3 - 4 } & & $\mathbf{1}$ & $\mathbf{2}$ \\
\hline \multirow{3}{*}{$\mathbf{B}$} & 1 & A1B1 & A2B1 \\
& 2 & A1B2 & A2B2 \\
& 3 & A1B3 & A2B3 \\
\hline
\end{tabular}

Keterangan:
A : Pembelajaran
A1 : Menggunakan CUPs
A2 : Menggunakan DI
B : Kreativitas Belajar
B1 : Kreativitas Belajar Tinggi

\section{B2 : Kreativitas Belajar Sedang \\ B3 : Kreativitas Belajar Rendah}

Populasi adalah sesuatu yang memiliki kualitas dan karakteristik tertentu yang ditetapkan oleh peneliti untuk dipelajari dan kemudian ditarik kesimpulannya (John W Creswell, 2014). Populasi pada penelitian ini adalah kelas XI IPA SMA Negeri 5 Bandar Lampung sebanyak 212 peserta didik. Sampel ialah bagian dari jumlah dan karakteristik yang dimiliki populasi. Sampel pada penelitian adalah kelas XI IPA 3 sebagai kelas eksperimen sebanyak 36 peserta didik menggunakan model pembelajaran pembelajaran Conceptual Understanding Procedures (CUPs) disertai teknik Mind Mapping dan XI IPA sebagai kelas kontrol sebanyak 35 peserta didik menggunakan model pembelajaran Direct Instruction.

Teknik pengumpulan data pada penelitian ini menggunakan test (Postest), angket, wawancara dan dokumentasi. Analisis data penelitian menggunakan Analisis Variansi Dua Jalan Sel Tak Sama yang sebelumnya telah melalui uji prasyarat yaitu Uji Normalitas dan Uji Homogenitas.

\section{HASIL DAN PEMBAHASAN Hasil Penelitian}

Hasil perhitungan data menggunakan analisis variansi dua jalan tak sama disajikan seperti tabel dibawah ini :

Tabel 2. Hasil Uji Analisis Variansi Dua Jalan Sel Tak Sama

\begin{tabular}{cccccc}
\hline Sumber & JK & DK & RK & $\mathbf{F}_{\text {hit }}$ & $\mathbf{F}_{\text {tab }}$ \\
\hline CUPs (A) & & & & & \\
& 3799,662 & 1 & 3799,662 & 119,917 & 3,989 \\
KB (B) & & & & & \\
& 9903,104 & 2 & 4951,552 & 156,271 & 3,138 \\
Interaksi & & & & & \\
& 3868,510 & 2 & 1934,255 & 61,05 & 3,138 \\
Galat & 2059,568 & 65 & 31,686 & - & - \\
Total & 19630,843 & 70 & - & - & - \\
& & & & &
\end{tabular}

Keterangan:

A : Model Pembelajaran CUPs

B : Kreativitas Belajar

JK : Jumlah Kuadrat 
Quagga: Jurnal Pendidikan dan Biologi

Volume 12, Nomor 1, Januari 2020, pp. 85-93
p-ISSN 1907-3089, e-ISSN2651-5869

https://doi.org/10.25134/quagga.v12i1.2102
DK : Derajat Kebebasan

RK : Rataan Kuadrat

Berdasarkan hasil perhitungan tersebut, didapatkan hasil $\mathrm{F}_{\mathrm{a} \text { hitung }} 119,917>\mathrm{F}_{\mathrm{a} \text { tabel }} 3,989$ dapat disimpulkan bahwa $\mathrm{H}_{0 \mathrm{~A}}$ ditolak yang artinya terdapat perbedaan pemahaman konsep peserta didik antara kelas yang menggunakan model pembelajaran Conceptual Understanding Procedures (CUPs) disertai teknik Mind Mapping dengan kelas kontrol yang menggunakan model Direct Instruction, $\mathrm{F}_{\mathrm{b}}$ hitung $156,271>\mathrm{F}_{\mathrm{b}}$ tabel 3,138 dapat disimpulkan bahwa $\mathrm{H}_{0 \mathrm{~B}}$ ditolak yang artinya terdapat perbedaan pemahaman konsep peserta didik yang mempunyai kreativitas belajar tinggi, sedang, dan rendah, dan $\mathrm{F}_{\mathrm{ab} \text { hitung }}<\mathrm{F}_{\mathrm{ab} \text { tabel }}$ 61,05 dapat disimpulkan bahwa $\mathrm{H}_{0 \mathrm{AB}}$ diterima yang berarti bahwa tidak terdapat interaksi antara penggunaan model pembelajaran Conceptual Understanding Procedures (CUPs) disertai teknik Mind Mapping dengan kreativitas belajar terhadap pemahaman konsep peserta didik.

Dapat dilihat pada gambar diagram ini, hasil persentase dari masing-masing indikator pemahaman konsep antara kelas eksperimen dan kelas kontrol.

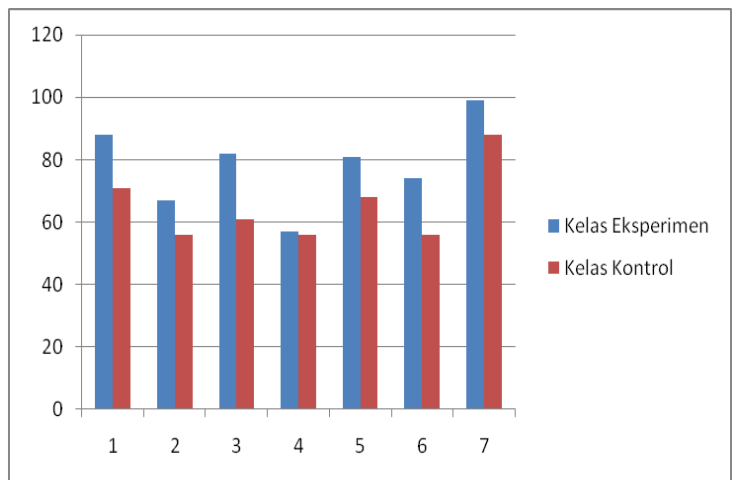

Gambar 1. Persentase indikator pemahaman konsep antara kelas eksperimen dan kelas kontrol

Keterangan:

Indikator Pemahaman Konsep

1: Interpreting (menafsirkan)

2: Exempliying (mencontohkan)

3: Calssifying (mengklasifikasikan)

4: Summarizing (merangkum)

5: Inferring (menyimpulkan)
6: Comparing (membandingkan)

7: Explaining (menjelaskan)

\section{Pembahasan}

Berdasarkan hasil perhitugan diketahui nilai rata-rata Postest kelas eksperimen yang menggunakan model pembelajaran Conceptual Understanding Procedures (CUPs) disertai teknik Mind Mapping yaitu sebesar 78,19 mempunyai hasil lebih tinggi dari kelas kontrol yang menggunakan model pembelajaran Direct Instruction sebesar 64. Dengan demikian, dapat disimpulkan bahwa terdapat perbedaan pemahaman konsep antara penggunan model pembelajaran Conceptual Understanding Procedures (CUPs) disertai teknik Mind Mapping dengan penggunaan model pembelajaran Direct Instruction.

Pemahaman konsep dapat dipengaruhi oleh model pembelajaran yang digunakan dan kreativitas belajar yang dimiliki oleh peserta didik. Model pembelajaran Conceptual Understanding Procedures (CUPs) cocok untuk peserta didik yang memiliki kreativitas belajar tinggi namun tidak cocok untuk peserta didik yang kreativitas belajarnya rendah. Hal ini disebabkan karena pada model pembelajaran Conceptual Understanding Procedures (CUPs) peserta didik harus aktif baik secara mandiri maupun kelompok. Pemahaman merupakan jenjang kemampuan berfikir yang setingkat lebih tinggi dari ingatan atau hafalan. Tidak hanya sekedar mengingat atau menghapal, memahami sesuatu itu apabila peserta didik bisa memberikann penjelasan yang lebih rinci lagi dengan mempergunakan kata-kata yang dirancangnya sendiri (Yulilina Retno, Rusdi, Amalia, 2016).

Dengan demikian, apabila peserta didik memiliki kreativitas belajar yang tinggi maka akan lebih mudah pula peserta didik tersebut memahami konsep, permasalahan, ataupun materi pelajaran. Proses belajar mengajar ini yang diharapkan dapat memberikan pengaruh positif terhadap pemahaman konsep peserta didik. Hal ini dapat dilihat pada hasil perhitungan uji Annava pada tabel 3.1 di atas. Pada proses pengukuran kreativitas belajar peserta didik dengan menggunakan angket berupa pernyataan positif dan pernyataan 
negatif, peserta didik yang diketahui memiliki pemahaman konsep yang tinggi dapat lebih mudah mengisi angket kreativitas belajar yang telah diberikan. Sedangkan, peserta didik yang pemahaman konsepnya tergolong rendah cenderung asal-asalan karena tidak memahami pernyataan dalam angket kreativitas belajar.

Tidak adanya interaksi antara model pembelajaran dengan kreativitas belajar terhadap pemahaman konsep peserta didik ini diakibatkan oleh peserta didik yang kurang fokus pada saat proses belajar dengan alasan mereka merasa lelah karena terlalu banyak tugas dari mata pelajaran lain yang mengakibatkan mereka tidak bersungguhsungguh dalam mengikuti pembelajaran sehingga materi yang diterima tidak maksimal dan tidak jujur dalam mengisi angket.

Kreativitas belajar pada peserta didik sangatlah berperan penting dalam peningkatan hasil belajar. Kreativitas belajar peserta didik yang tinggi maka hasil belajarnya pun akan tinggi (Roida Eva \& Maya Nurfitriyanti, 2015). Dengan demikian, apabila peserta7didik memiliki kreativitas belajar yang tinggi maka akan lebih mudah pula peserta didik tersebut memahami konsep, permasalahan, ataupun materi pelajaran (Riska Purnama S, 2017).

Menumbuhkan kreativitas belajar peserta didik perlu usaha yang tidak mudah untuk dilakukan, pendidik perlu meninjau kembali kreativitas peserta didik bahwa peserta didik mempunyai kreativitas yang terasah memang dari dirinya sendiri bukan karena ingin mendapatkan penghargaan atau pujian dari pendidik. Peserta didik yang memang memiliki kreativitas belajar tentunya akan mempunya jiwa kreatif, rasa ingin tahu, dan tidak puas baik dalam menemukan informasi dan pembelajaran dikelas (Mukhlison Effendi, 2016).

Mind Mapping membantu penggunaan kedua belah otak secara seimbang. Interaksi yang luar biasa antara kedua belahan otak dapat memicu kreativitas. Mind Mapping sangat berperan dalam pembelajaran, setiap orang pada dasarnya memiliki bakat kreatif dan kemampuan untuk mengungkapkan dirinya secara kreatif meskipun dalam kadar yang berbeda. Dengan menggunakan Mind mapping peserta didik terbantu mengingat dan memahami materi dengan cara yang bervariasi, tidak membosankan, dan dapat melatih pemahaman konsep dalam belajar (Dewa Ayu Made Manu Okta Priantini, 2016).

Proses belajar dengan menggunakan model pembelajaran Conceptual Understanding Procedures (CUPs) dapat melibatkan peserta didik untuk memahami konsep, membuat kesimpulan, mengidentifikasi, dan memberikan contoh. Dengan kata lain, CUPs model pembelajaran yang bertujuan untuk membantu meningkatkan pemahaman konsep yang dianggap sulit oleh peserta didik. Apabila belajar berdasarkan pemahaman konsep secara menyeluruh, bukan hanya sekedar hafalan, pengetahuan yang dimiliki akan lebih bertahan lama di ingatan dan hal tersebut dapat mengoptimalkan hasil belajar peserta didik (Irdana Prastiwi dan Edi Soedjoko, 2014).

Pemahaman konsep dapat dikembangkan melalui kegiatan pembelajaran yang ada pada model pembelajaran Conceptual Understanding Procedures (CUPs) disertai teknik Mind Mapping diantaranya mengembangkan pemikiran dan pemahaman peserta didik, peserta didik dapat menemukan konsepnya sendiri, mengembangan rasa ingin tahu peserta didik dengan kegiatan bertanya, menciptakan suasana belajar aktif, dan menghadirkan suatu model dalam pembelajarannya. Dengan model pembelajaran ini peserta didik harus memahami materi atau menyelesaikan masalah dan pendidik hanya memberikan arahan untuk memperoleh keaktifan kelas secara menyeluruh (D. R Shelena Nugraha R. Dewi, Reduk Nilawarni, 2015).

Penelitian ini dalam proses pembelajaran yang berlangsung di kelas eksperimen peserta didik lebih aktif, memiliki rasa ingin tahu yang lebih, dan kreativitas yang lebih baik saat proses pembelajaran dibandingkan dengan kelas kontrol. Proses pembelajaran yang diterapkan di kelas memang masih terdapat kendala dimana peserta didik masih bertanya mengenai apa saja yang harus mereka lakukan saat pembelajaran berlangsung. Hal tersebut menjadikan pendidik harus dapat menuntun peserta didik untuk menerapkan setiap tahapan pembelajaran yang akan dilakukan. Dengan 
penelitian ini diharapkan peserta didik dapat melatih kemampuan peserta didik dalam memahami konsep pada materi yang diajarkan dan dapat membantu menimbulkan kekreativitasan peserta didik dalam belajar. Kreativitas belajar pada peserta didik sangatlah berperan penting dalam peningkatan hasil belajar. Peserta didik yang mempunyai kreativitas belajar yang tinggi maka memungkinkan hasil belajarnya pun tinggi dengan menggunakan model strategi, dan metode pembelajaran yang tepat (Rijal Darusman, 2015).

Diperlukan inovasi baru dalam pembelajaran yang membantu peserta didik memahami konsep suatu materi yaitu pembelajaran konstruktivis. Pembelajaran konstruktivis ini akan melibatkan interaksi antara pengetahuan baru dan pengetahuan lama yang telah peserta didik miliki sebelumnya. Salah satu model pembelajaran yang dapat diterapkan dalam pelajaran biologi adalah model pembelajaran Conceptual Understanding Procedures (CUPs) (Asri Gita, Nerru Pranuta Murnaka and Klara Iswara Sukmawati, 2018).

Keberhasilan dalam proses pembelajaran juga dipengaruhi oleh peran pendidik, pendidik sebagai pengarah, sebagai motivator, dan inspirator dalam belajar maka peserta didik akan selalu memiliki keinginan tinggi dan peserta didik bisa lebih fokus dalam pembelajaran sehingga tujuan pembelajaran bisa tercapai dengan maksimal (Gunawan Ibrahim, Kosim, 2017). Proses pembelajaran juga harus dengan perencanaan yang baik, terarah, dan maksimal. Semua proses harus terukur dengan jelas sehingga tidak ada waktu yang terbuang sia-sia. Perencanaan yang baik akan menghasilkan hasil belajar yang baik juga. Selain itu, pemilihan model pembelajaran, metode, ataupun pendekatan menjadi salah satu hal yang penting untuk dipilih dan digunakan sesuai dengan rencana pelaksanaan pembelajaran yang cocok dan berkesinambungan sehingga hasil pembelajaran yang diperoleh sesuai dengan tujuan pembelajaran yang ingin dicapai.

\section{SIMPULAN}

Berdasarkan hasil penelitian di atas, dapat disimpulkan bahwa terdapat perbedaan pemahaman konsep antara kelas eksperimen dengan menggunakan model pembelajaran Conceptual Understanding Procedures (CUPs) disertai teknik Mind Mapping dengan kelas kontrol menggunakan model pembelajaran Direct Instruction ; terdapat perbedaan pemahaman konsep menggunakan dengan menggunakan model pembelajaran Conceptual Understanding Procedures (CUPs) disertai teknik Mind Mapping pada peserta didik yang mempunyai kreativitas tinggi, sedang, dan rendah ; tidak terdapat interaksi antara penggunaan model pembelajaran Conceptual Understanding Procedures (CUPs) disertai teknik Mind Mapping dengan kreativitas belajar terhadap pemahaman konsep peserta didik.

\section{REFERENSI}

Amalia, Rusdi, Retno, Yulilina, 2016, 'Pengaruh Model Pembelajaran Concept Attainment Terhadap Kemampuan Komunikasi Dan Pemahaman Konsep Siswa Pada Materi Sistem Reproduksi', Jurnal Biosfer: Jurnal Pendidikan Biologi, Vol.9, No.2.

Bolandifar, Saeideh, Noordin, Nooreen, 2013, 'Investigating the Relationship between Creativity and Academic Achievement of Malaysian Undergraduates', Jurnal Teknologi Social Science.

Creswell, John W, 2014, Research Design Qualitative, Quantitative, and Mixed Methods Approaches, USA, SAGE Publication, Inc.

Darusman, Rijal, 2015, 'Penerapan Metode Mind Mapping (Peta Pikiran) Untuk Meningkatkan Kemampuan Berpikir Kreatif Matematik Siswa Smp', Infinity Journal, Vol.3, No.2.

Deta, UA, Widha, S, 2013, 'Pengaruh Metode Inkuiri Terbimbing dan Proyek, Kreativitas, Serta Keterampilan Proses Sains Terhadap Prestasi Belajar Siswa', Jurnal Pendidikan Fisika Indonesia, Vol. 9, No. 1. 
Quagga: Jurnal Pendidikan dan Biologi

Volume 12, Nomor 1, Januari 2020, pp. 85-93

Effendi, Mukhlison, 2016, 'Integrasi Pembelajaran Active Learning dan Internet-Based Learning dalam Meningkatkan Keaktifan dan Kreativitas Belajar', Jurnal Pendidikan Islam.

Indrowati, Meti, Setiyawan, Dedy, Nurmiyati, 2016, 'Perbandingan Model Pembelajaran Discovery Berbantu Peta Konsep Dan Model Pembelajaran Discovery Terhadap Pemahaman Konsep Protista Siswa Kelas X SMA Negeri 1 Sukaharjo Tahun Pelajaran 2014/2015', Jurnal Bio- Pedagogi, Vol.5, No.1.

Ismawati, F, Nugroho, Dwijananti, P, 2014, "Penerapan Model Pembelajaran Conceptual Understanding Procedures Untuk Meningkatkan Curiosty Dan Pemahaman Konsep Siswa." Jurnal Pendidikan Fisika Indonesia.

Izzati, Nurma, 2016, 'Meningkatkan Kemampuan Pemahaman Konsep Matematis Mahasiswa Pada Mata Kuliah Kapita Selekta Melalui Penerapan Model Pembelajaran Mind Mapping', Tadris Matematika, Jurnal Tadris Matematika, Vol.5, No.1.

Kosim, Ibrahim, Gunawan, 2017, 'Pengaruh Model Pembelajaran Conceptual Understanding Procedures (CUPs) Berbantuan LKPD Terhadap Kemampuan Pemecahan Masalah', Jurnal Pendidikan Fisika Dan Teknologi, Vol.3, No.1.

Kurniasih, Nining, Haka, Bidayati Nukhbatul, 2017, 'Penggunaan Tes Diagnostik Two-Tier Multiple Choice Untuk Menganalisis Miskonsepsi Siswa Kelas X Pada Materi Archaebacteria Dan Eubacteria', Biosfer: Jurnal Tadris Biologi, Vol. 8, No.1.

L, Maulvi, Awwalia, 2015, 'Pengaruh Model Pembelajaran Resiprocal Teaching Terintregasi Mind Mapping Terhadap Hasil Belajar Pada Konsep Sistem Sirkulasi', Jurnal Pendidikan.

Majid, Abdul, 2013, Strategi Pembelajaran, Bandung, PT. Rosdakarya.

Nilawarni, Reduk, Dewi, R., Shelena, R., D.,
p-ISSN 1907-3089, e-ISSN2651-5869

https://doi.org/10.25134/quagga.v12i1.2102

Nugraha, 2015, 'Penerapan Model Conceptual Understanding Procedures (Cups) Dan Concept Attainment Model (Cam) Terhadap Reduksi Miskonsepsi Siswa Pada Materi Sistem Pencernaan', Jurnal Biosfer, Vol.8, No.1.

Nurfitriyanti, Eva, Roida, Maya, 2015, 'Metode Pembelajaran Inquiry Dan Pengaruhnya Terhadap Hasil Belajar Matematika Ditinjau Dari Kreativitas Belajar', Jurnal Pendidikan Matematika.

Prastiwi, Irdana, Soedjoko, Edi, 2014, 'Efektivitas Pembelajaran Conceptual Understanding Procedures Untuk Meningkatkan Kemampuan Siswa Pada Aspek Koneksi Matematika', Jurnal Matematika Kreatif-Inovatif, Vol. 5, No.1.

Priantini, Okta, Manu, 2016, 'Pengaruh Metode Mind Mapping Terhadap Keterampilan Berpikir Kreatif Dan Prestasi Belajar IPS', Jurnal Keguruan dan Ilmu Pendidkan Universitas Dwijendra.

Rosdianto, Haris, 2017, 'Students' Conceptual Understanding through Generative Learning Model in Topic Light', Jurnal Pendidikan Indonesia, Vol. 6, No .2.

S, Purnama, Riska, 2017, 'Meningkatkan Pemahaman Konsep Dan Kreativitas Belajar SiswaMelalui Proyek Multimedia Tentang Sel Pada Siswa SMK', Jurnal Pendidikan Biologi.

Sahara, La, 2015, 'Penerapan model concept teaching pendekatan Concept attainment untuk0meningkatkan0pemahaman8kon sep', Jurnal Pendidikan8Fisika Dan Teknologi, Vol.I, No.2.

Sugiyono, 2016, Metode Penelitian Pendidikan, Bandung, Alfabeta.

Sukmawati, Iswara, Klara, Murnaka, Pranuta, Nerru, Gita, Asri, 'Penerapan Model Pembelajaran Conceptual Understanding Procedures (CUPS) Sebagai Upaya Mengatasi Miskonsepsi Matematis Siswa', Journal of Medives : Journal of Mathematics Education IKIP Veteran Semarang, Vol.2, No.1.

Sumantri, Syarif, Mohammad, 2016, Strategi 
Pembelajaran, Jakarta, PT. Raja Grafindo Persada.

Sunarto, 2018, 'Pengembangan KreativitasInovatif Dalam Pendidikan Seni Melalui Pembelajaran Mukidi', Jurnal Refleksi Edukatika, Vol.8, No.2.

Tatang, Anwar, Japar, Muh, 2018, 'The Effectiveness of Career Information Service with Mind Mapping Technique to Improve Students Occupational Knowledge', Jurnal Bimbingan Konseling, Vol. 7, No.1.

Uno, B, Hamzah, 2012, Perencanaan Pembelajaran, Jakarta, PT. Bumi Aksara.

Wiarta, Wyn I, Anggreni, Rita, Kd, Meter, Gd, I., 2013, 'Model Pembelajaran Conceptual Understanding Procedures Berpengaruh Terhadap Hasil Belajar Matematika Siswa Kelas V SD Gugus VII Kompiang Sujana Denpasar Barat', Ejournal Universitas Pendidikan Ganesha, Vol.1, No.1. 